\title{
UPAYA MENINGKATKAN MOTIVASI SISWA DAN HASIL BELAJAR SISWA PADA MATA PELAJARAN ALQU'RAN HADITS TENTANG MATERI MELESTARIKAN ALAM MELALUI MODEL PEMBELAJARAN KOOPERATIF TIPE JIGSAW SISWA KELAS IXF MTS NEGERI BONANG KECAMATAN BONANG KABUPATEN DEMAK SEMESTER I TAHUN PELAJARAN 2017/2018
}

\author{
Rofi'i \\ MTs Negeri 5 Demak Jawa Tengah \\ E-mail: bonangdemak123@gmail.com
}

\begin{abstract}
Abstrak
Tujuan penelitian ini adalah untuk mengetahui apakah penggunaan model pembelajaran kooperatif tipe jigsaw dapat meningkatkan hasil dan aktivitas belajar siswa kelas IXF pada mata pelajaran AlQur'an Hadits materi tentang Kelestarian alam di MTs Negeri Bonang Kecamatan Bonang Kabupaten Demak. Metode Penelitian yang digunakan dalam penelitian ini adalah Penelitian Tindakan Kelas (PTK). Penelitian ini menerapkan 2 siklus yaitu siklus I dan siklus II. Setiap siklusnya terdiri dari empat tahapan yaitu perencanaan, tindakan, observasi, dan refleksi dan hasil belajar Hasil penelitian ini model pembelajaran kooperatif tipe jigsaw dapat meningkatkan motivasi belajar Al Qur'an Hadits tentang Kelestarian alam siswa kelas IXF MTs Negeri Bonang semester 1 tahun pelajaran 2017/2018, dari rata- rata Pra Siklus sebesar 69 mengalami peningkatan di Siklus I sebesar 81 dengan Siklus II menjadi 91, Melalui model pembelajaran kooperatif tipe jigsaw, hasil belajar Al Qur'an Hadits materi Kelestarian alam siswa kelas IXF MTs Negeri Bonang semester 1 tahun pelajaran 2017/2018 dapat meningkat sebesar 22 dari nilai rata-rata 64 menjadi 86 . Sedangkan, ketuntasan belajar terjadi peningkatan sebesar $77 \%$ dari yang tuntas $14 \%$ menjadi $91 \%$ terjadi kenaikan yang sangat Signifikan.
\end{abstract}

Kata kunci: motivasi siswa, hasil belajar sisswa, tipe jigsaw

\begin{abstract}
The purpose of this study was to determine whether the use of a jigsaw cooperative learning model can improve the learning outcomes and learning activities of IXF graders on Al-Qur'an subjects of material about nature preservation in MTs Negeri Bonang, Bonang District, Demak Regency. The research method used in this study is Classroom Action Research (CAR). This study applies two cycles, namely cycle I and cycle II. Each cycle consists of four stages, namely planning, action, observation, and reflection and learning outcomes. The results of this study are a jigsaw cooperative learning model that can increase motivation to learn Al-Hadith about the natural preservation of class IXF students at MTs Negeri Bonang semester 1 of 2017 / academic year 2018, from the average Pre-Cycle of 69 increased in Cycle I by 81 with Cycle II to 91, Through the jigsaw type cooperative learning model, the learning outcomes of the Qur'an Hadith Natural preservation material for students of class IXF MTs Negeri Bonang semester 1 semester 2017/2018 can be increased by 22 from an average value of 64 to 86. Meanwhile, mastery learning has increased by $77 \%$ from complete $14 \%$ to $91 \%$ there was a very significant increase. Keywords: student motivation, student learning outcomes, jigsaw type
\end{abstract}

\section{Info Artikel}

Diterima Oktober 2019, disetujui November 2019, diterbitkan Desember 2019 


\section{PENDAHULUAN}

Sebuah pembelajaran yang ideal dan dapat dikatakan berhasil jika hasil proses pembelajaran tercapai sesuai indikator yang diinginkan dan target nilai yang ditentukan oleh masing-masing pendidik. Keberhasilan tersebut akan lebih bermakna jika didukung dengan strategi pembelajaran yang diterapkan oleh guru serta motivasi siswa yang sangat tinggi terhadap belajar. Karena dari sisi siswa, hasil belajar merupakan tingkat perkembangan mental yang lebih baik bila dibandingkan pada saat sebelum belajar (Dimyati dan Mudjiono).

Pemilihan strategi dalam pembelajaran yang dilakukan guru sangat berpengaruh terhadap semangat belajar siswa. Dalam hal ini guru memiliki keahlian dalam menentukan strategi/metode yang relevan baik dengan karakteristik materi maupun dengan tingkat kemampuan siswa. Oleh karena itu, berdasarkan saran, nasehat, dan diskusi dengan teman sejawat, guru ingin melakukan tindakan perbaikan melalui Penelitian Tindakan Kelas (PTK) pada pelajaran AlQur'an Hadits Kompetensi Dasar Meyakini pentingnya menjaga kelestarian alam dengan menggunakan metode kooperatif tipe jigsaw. Pembelajaran kooperatif tipe jigsaw sangat tepat sekali untuk mengajarkan materi tersebut, karena metode kooperatif tipe jigsaw menekankan pada kerja sama sehingga dengan metode tersebut, siswa akan lebih bersemangat mengikuti pembelajaran sehingga hasil belajar siswa meningkat.

\section{METODE PENELITIAN}

Penelitian ini dilaksanakan selama 5 bulan, yaitu Juli s.d November pada semester ganjil tahun pelajaran 2017/2018. Model penelitian tindakan kelas ini menggunakan sistem spiral refleksi diri yang dimulai dari rencana, tindakan, pengamatan, refleksi, dan perencanaan kembali yang merupakan dasar untuk suatu ancang-ancang pemecahan masalah. peneliti menggunakan model ini karena dianggap paling praktis dan aktual. Berdasarkan hasil refleksi ini, peneliti dapat melakukan perbaikan terhadap rencana awal. prosedur pelaksanaan perbaikan pembelajaran dilaksanakan dua siklus yang masing-masing siklus melalui empat tahapan, yaitu tahap perencanaan, tahap pelaksanaan, tahap observasi atau pengumpulan data, dan tahap refleksi.

\section{Perencanaan}

Setelah pra siklus, peneliti membuat rencana perbaikan pembelajaran kemudian dikonsultasikan kepada teman sejawat dan kepala sekolah, ternyata masih banyak kekurangan karena metode pembelajaran masih konvensional sehingga langsung direvisi. Pada siklus i, peneliti melakukan perbaikan dengan menerapkan model pembelajaran kooperatif tipe jigsaw dalam pembelajaran.

\section{Tahap Pelaksanaan}

Rencana pembelajaran yang sudah direvisi oleh teman sejawat dan kepala sekolah, peneliti akan melaksanakan perbaikan pembelajaran. Kompetesi Dasar yang penulis laksanakan adalah tentang memelihara kelestarian alam. Dalam siklus I, peneliti dibantu oleh teman sejawat

\section{Tahap Pengamatan}

Pengamatan dilaksanakan pada saat proses pembelajaran berlangsung yang dilakukan oleh teman sejawat. Tugas teman sejawat adalah mengamati selama proses pembelajaran berlangsung dengan alat lembar pengamatan. Lembar pengamatan yang 
digunakan berupa lembar pengamatan motivasi siswa, kegiatan pembelajaran,. Adapun hal-hal yang diamati adalah:

a. Guru

Penggunaan media pembelajaran

Penguasaan materi

Metode pembelajaran yang digunakan

b. Siswa

Motivasi siswa dan tanya jawab

c. Hasil belajar Al Qur'an Hadits

Ketuntasan belajar di atas KKM 75

\section{Tahap Refleksi}

Dalam tahap refleksi peneliti bersama teman sejawat menganalisis mengenai proses dan hasilnya selama siklus I dilaksanakan. Analisis tersebut mengenai kekurangan dan kelebihan pada siklus I serta menentukan langkah berikutnya. Untuk mengatasi kelemahan adalah mengefektifan kegiatan proses perbaikan pembelajaran selanjutnya pada siklus II.

\section{HASIL PENELITIAN DAN PEMBAHASAN}

Hasil penelitian bahwa motivasi belajar siswa menunjukkan keberhasilan dimana ditunjukkan dengan peningkatan setiap siklus. Hal itu dapat dilihat dalam tabel 1 . berikut ini.

Tabel 1.

Rekapitulasi Nilai Motivasi Siswa

\begin{tabular}{|c|c|c|c|c|}
\hline \hline No & Uraian & Pra Siklus & Siklus I & Siklus II \\
\hline 1 & Nilai rata-rata motivasi & 69 & 81 & 91 \\
\hline
\end{tabular}

Terlihat dari tabel di atas, tiap siklus terjadi peningkatan nilai rata-rata motivasi siswa yaitu dari pra siklus 69, siklus I 81, dan siklus II 91. Ini artinya setelah diupayakan perbaikan dalam pembelajaran dengan menerapkan model pembelajaran kooperatif tipe jigsaw motivasi siswa terhadap pelajaran Al Qur'an Hadits lebih semangat saat proses pembelajaran.

Begitu pula hasil belajar siswa menunjukkan bahwa kemampuan siswa dalam memahami materi dengan menggunakan model pembelajaran kooperatif tipe jigsaw dapat memenuhi harapan sehingga tujuan instruksional dapat tercapai. Melihat hasil tes uraian untuk mengukur keberhasilan pada pra siklus dan siklus pertama ternyata tingkat ketuntasannya rendah. Beberapa indikator masih tampak dengan jelas bahwa tingkat penguasaan materi belum dimiliki siswa. Siswa masih bingung dalam kelestarian alam. Setelah diadakan perbaikan pembelajaran pada siklus II, akhirnya siswa dapat menguasai materi dengan baik. 
Peningkatan hasil belajar siswa dapat dilihat dalam table 2. berikut:

Tabel 2.

Rekapitulasi Hasil Belajar Siswa

\begin{tabular}{|c|l|c|c|c|}
\hline \hline No & \multicolumn{1}{|c|}{ Uraian } & Pra Siklus & Siklus I & Siklus II \\
\hline 1 & Nilai rata-rata & 64 & 79 & 86 \\
\hline 2 & Ketuntasan belajar & $14 \%$ & $80 \%$ & $91 \%$ \\
\hline
\end{tabular}

Pada siklus kedua, nilai rata-rata meningkat pada Pra Siklus 64, siklus I 79, dan Siklus II 86. Peningkatan juga terjadi pada ketuntasan dengan hasil belajar yang memuaskan dibanding siklus sebelumnya yaitu dari pra siklus $14 \%$, Siklus I $80 \%$, dan Siklus II $91 \%$.

Peningkatan hasil belajar Al Qur'an Haditsdari pra siklus hingga siklus II. Pada siklus II ketuntasan hasil belajar dapat tercapai 91\%. Sehingga dapat dikatakan setelah dilakukan perbaikan pembelajaran hingga siklus II, hasil belajar siswa meningkat.

Dalam pembelajaran AlQur'an Hadits pengungkapan materi yang tidak pernah diterima atau dikuasai siswa dari kelas sebelumnya merupakan suatu langkah yang tidak boleh ditinggalkan. Beberapa materi juga perlu dilatih ketrampilan prosesnya agar siswa betul-betul belajar mempunyai makna, belajar bukan hanya sekedar menerima, tetapi dengan mengalami kesan siswa akan membekas tidak pernah lupa, dan dapat menambah pengalaman siswa yang sebelumnya belum pernah didapat sebelumya, serta siswa mendapatkan lebih banyak medapatkan model model pembelajaran.

\section{KESIMPULAN}

Dari pembelajaran dan perbaikan pembelajaran tiap siklus yang telah dilakukan, maka dapat disimpulkan:

1. Melalui model pembelajaran kooperatif tipe jigsaw dapat meningkatkan motivasi belajar Al Qur'an Hadits tentang Kelestarian alam siswa kelas IXF MTs Negeri Bonang semester 1 tahun pelajaran 2017/2018, dari rata- rata Pra Siklus sebesar 69 mengalami peningkatan di Siklus I sebesar 81 dengan Siklus II menjadi 91.

2. Melalui model pembelajaran kooperatif tipe jigsaw, hasil belajar Al Qur'an Hadits materi Kelestarian alamsiswa kelas IXF MTs Negeri Bonang semester 1 tahun pelajaran 2017/2018 dapat meningkat sebesar 22 dari nilai rata-rata 64 menjadi 86. Sedangkan, ketuntasan belajar terjadi peningkatan sebesar $77 \%$ dari yang tuntas $14 \%$ menjadi $91 \%$ terjadi kenaikan yang sangat Signifikan,

3. Sehingga dapat disimpulkan pembelajaran dengan menggunakan metode Tipe jigsaw dapat meningkatkan motivasi siswa dan meningkatkan hasil belajar siswa pada materi kelestarian lingkungan kelas IXF MTs Negeri Bonang tahun pelajaran 2017/2018. 


\section{DAFTAR PUSTAKA}

Ahmad Susanto. 2013. Teori Belajar dan Pembelajaran di Sekolah Dasar.Jakarta: Kencana Prenadamedia Group

Aqib, Zainal. (2006). Penelitian Tindakan Kelas untuk Guru. Bandung: Yrama Widya.

Arikunto, Suharsimi. 2013. Dasar-Dasar Evaluasi Pendidikan Edisi 2. Jakarta: PT Bumi Aksara. 2010. Penelitian Tindakan Kelas. Jakarta: PT Bumi Aksara.

Depdiknas. 2003. Undang-Undang No. 20 tahun 2003 tentang Sistem Pendidikan Nasional. Jakarta: DepdiknasArikunto, Suharsimi. 2009. Dasar-Dasar Evaluasi Pendidikan. Jakarta : Bumi Aksara.

Rineka Cipta. 2010. Prosedur Penelitian Suatu Pendekatan Praktik. Jakarta : PT

Dimyati \& Mudjiono. 2006. Belajar dan Pembelajaran. Jakarta: Rineka Cipta

Djaali, H. 2006. Psikologi Pendidikan. Jakarta : Bumi Aksara.

Hindarto, N., \& Anwar, K. (2007). Pengaruh Kemahiran Berproses Terhadap Hasil Belajar Siswa SMA Melalui Model Pembelajaran Kooperatif. Lembaran Ilmu Kependidikan,

Sardiman. 2001. Interaksi Motivasi Belajar Mengajar. Jakarta: PT Raja Grafindo Persada.

Slavin, Robert E. 2011. Cooperative Learning Teori, Riset dan Praktik. Bandung : Nusa Media.

Slameto. 2010. Belajar dan Faktor-faktor yang Mempengaruhinya. Jakarta: Rineka Cipta.

Soegeng. 2007. Filsafat Pendidikan. Semarang : IKIP PGRI PRESS.

Soenarjo, RJ. 2008. AL QUR'AN HADITS 5 Untuk MTS dan MI Kelas 5. Jakarta : Pusat Perbukuan Departemen Pendidikan Nasional.

Sudjana. 2005. Metode Statistika. Bandung: PT Tarsito Bandung.

Sugiyono. 2010. Metode Penelitian Pendidikan (Pendekatan Kuantitatif, kualitatif, danR\&D). Bandung:Alfabeta.

Supardi dan Suhardjono. 2012. Strategi Menyusun Penelitian Tindakan Kelas. Yogyakarta: ANDI Offset. 
Suprihatiningrum, Jamil. 2013. Strategi Pembelajaran: Teori \& aplikasi. Yogyakarta: Ar-Ruzz Media.

Suprijono, Agus. 2009. Cooperative Learning: teori \& aplikasi PAIKEM. Yogyakarta: Pustaka Pelajar. 